\title{
METAL CONNECTOR PLATE - EXPERIMENTAL DETERMINATION OF PLATE ANCHORAGE CAPACITY
}

\author{
Žikica Tekić, Aleksandra Nenadović, Saša Đorđević, Jefto Terzović
}

Original scientific paper This paper demonstrates the results of experimental determination of load bearing capacity of structural timber member connections realized by WOLF and LKVC metal connector plates. Considering the complexity of the connections realized by these modern mechanical fasteners, this paper deals only with plate anchorage capacity (stress in the metal-wood contact). The aim of the conducted experimental study was to determine the metal connector plate anchorage capacity in accordance with the provisions of Eurocode 5 and also to analyse the ratio of the load bearing capacities of these two types of connectors in terms of their geometry. Experimental testing was conducted by loading of multiple samples up to the limit plate anchorage capacity. Discussion of the test results included the analysis of the connection deformation for different levels of load, as well as the mode of reaching the limit plate anchorage capacity. Review of the determined limit plate anchorage capacities, for the determined displacements of connection, was given in the conclusion, together with the comment on test results.

Keywords: displacement; joint; limit bearing capacity; metal connector plate; tooth

Metalni konektor - eksperimentalno određivanje nosivosti bočne veze

Izvorni znanstveni članak

U radu je prikazano eksperimentalno određivanje nosivosti veza ostvarenih metalnim konektorima tipa WOLF i LKVC. S obzirom na kompleksnost veza ostvarenih ovim savremenim mehaničkim spojnim sredstvima, predmet rada obuhvaća samo nosivost bočne veze (naprezanje u spoju metal-drvo). Cilj provedenih eksperimentalnih ispitivanja je bio da se utvrdi nosivost bočne veze ostvarene metalnim konektorima, u skladu s odredbama Eurokoda 5 i da se paralelno s tim analizira odnos nosivosti ova dva tipa konektora, s aspekta njihove geometrije. Eksperimentalno ispitivanje je provedeno na više uzoraka, opterećivanjem uzoraka do dostizanja granične nosivosti bočne veze. Diskusija rezultata ispitivanja je obuhvatila analizu pomjerljivosti veza za različite nivoe opterećenja, kao i način dostizanja granične nosivosti bočne veze. U zaključku je dan komentar o utvrđenim graničnim nosivostima bočne veze, za određena pomjeranja veze, i zauzet je stav po pitanju dobivenih rezultata.

Ključne riječi: granična nosivost; metalni konektor; nastavak štapa; pomjeranje; zub

\section{Introduction}

Metal connector plates are modern mechanical fasteners, which are used in contemporary timber structures. The emergence of these fasteners was aimed to improve the level of production, in terms of simplicity of the connections of structural elements, namely, construction of the connections which will be of highquality and safe, in terms of transferring the load [1]. The primary function of the metal connector is to provide connection between members in the timber truss nodes and to form continuous joint between timber members. Metal connectors are made of galvanized steel sheet (or sheet of stainless steel) with thickness of $1,00 \mathrm{~mm}$ to 2,00 $\mathrm{mm}$, which is first perforated, whereupon the parts of the steel sheet are pulled from the sheet plane in the form of nails - teeth, positioned on a certain distance between each other, with the specific length and shape of the cross section.

In the world and in our country there are several standard types of metal connectors which are produced by sheet perforating and pulling the teeth perpendicular to a sheet plane. These types of connectors have been successfully used for the realization of connections between members of the timber trusses. The geometry of the standard types of metal connectors differs from manufacturer to manufacturer, in relation to the sheet thickness, the shape and the length and position of the teeth and the number of teeth per unit area. These parameters, as well as the production technology of standard types of metal connectors, affect the load bearing capacity of connections in timber structures. Load bearing capacity of metal connectors is determined experimentally in accordance with Eurocode 5 and it is used as a parameter for dimensioning of connections formed by metal connector plates.

For experimental determination of the load bearing capacity of connections formed by metal connectors, the connector LKVC type is chosen, whose manufacturer is LKV Centre from Serbia [2], as well as the connector WOLF $15 \mathrm{~N}$ type, whose manufacturer is WOLF from Austria [3]. Metal connectors are manufactured in accordance with the provisions of EN 10147 [4]. They have the same thickness of the sheet of $1,5 \mathrm{~mm}$, in order to make certain comparison in terms of load bearing capacity of realized connections. From the connectors geometry shown in Fig. 1, different teeth geometry, as well as their number - the ratio per unit area of connector, can be ascertained.

\section{Dimensioning of the connections formed by metal connectors}

During the dimensioning of the connection formed by metal connector, it is necessary to prove the adequate plate anchorage capacity, which includes analysis of stresses in the metal-wood contact, and to prove the adequate plate tension, compression and shear capacity, which includes analysis of stresses in the critical crosssection of the metal connector. Plate anchorage capacity is determined on the basis of laboratory tests, loading the test samples to the limit bearing capacity, for different positions of the longitudinal connector axis, in relation to the direction of the force and direction of the wood fibres. 
Typical values of stresses in the metal-wood contact, in the case of connections formed by metal connectors, are expressed per unit area of the metal connector plate, for specific angles $\alpha$ and $\beta$ [5], where:

$\alpha$ - angle between the direction of force and the direction of the longitudinal connector axis,

$\beta$ - angle between the direction of force and the direction of the longitudinal axis of the timber member.

Longitudinal connector axis is direction of the sheet rolling, namely, direction of the teeth pulling out of the sheet plane. The longitudinal axis of the timber member is defined by the direction of the wooden fibres.

Limit metal connector plate anchorage capacity is defined by the provisions of EN 1075 [6] and EN 28970 [7], in function of the limit load, effective connector area and wood density:
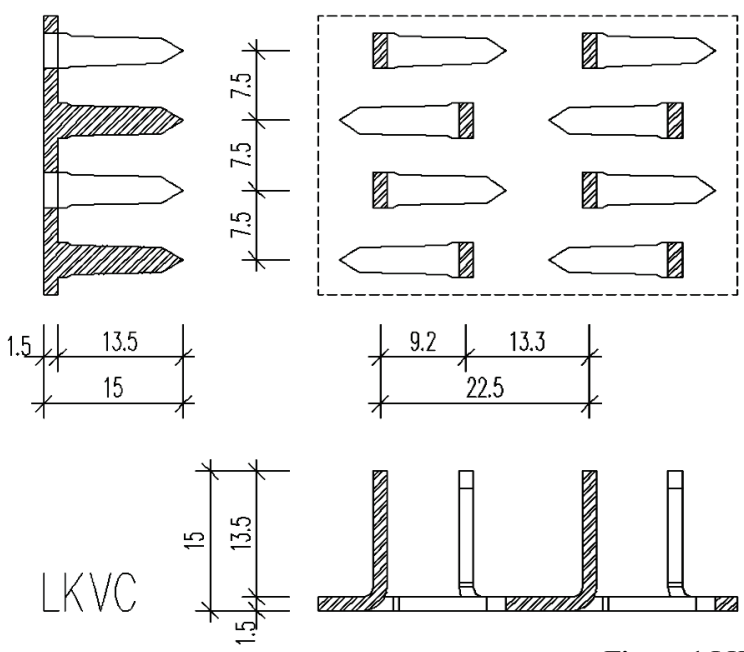

Figure 1 LKVC and WOLF metal connectors $f_{\mathrm{a}, \alpha, \beta}=\frac{F_{\alpha, \beta, \max }}{2 \cdot A_{\mathrm{ef}}} \cdot\left(\frac{\rho_{\mathrm{k}}}{\rho}\right)^{c}, \mathrm{MPa}$

where:

$f_{\mathrm{a}, \alpha, \beta}$ - limit plate anchorage capacity for given angles $\alpha$ and $\beta$ (for one connector in connection)

$F_{\mathrm{a}, \alpha, \beta, \max }$ - maximum (limit) load,

$A_{\text {ef }}$ - effective connector area,

$\rho_{\mathrm{k}}$ - characteristic density of wood, for certain class of wood,

$\rho$ - density of wood, for the test sample,

$c$ - dimensionless coefficient.

\section{Samples for experimental testing}

Experimental testing of plate anchorage capacity was conducted for the angle values of $\alpha=0^{\circ}$ and $\beta=0^{\circ}$. For determination of the limit metal connector plate anchorage capacity, in accordance with the provisions of EN 14545 [8], standard samples were tested, with 5 samples in one series, for the connector LKVC and the same for the connector WOLF (Fig. 2). The geometry of the samples was derived according to EN 1075. Connector dimensions were chosen in a way that approximately the same effective area for each connector type could be obtained, and at the same time that there is no fracture in the cross-section of connector, but only in the metal-wood contact zone. This is achieved by the ratio of connector length $L$ and connector width $B$, where $B>L / 2$. Wood that is used for samples is from class II conifers, with humidity of $15 \%$. The geometry of all the samples that were subjected to the test is shown in Fig. 2, noting that the width of the cross section of the wood element was $b=44 \mathrm{~mm}$.

The forming of samples was conducted in production facility of LKV Center from Belgrade. The embedding of the connector plates into the wood was performed by hydraulic press with the capacity of $240 \mathrm{kN}$. First, the connector plate was embedded on one side of the sample, and then on the other side of the sample (Fig. 3).

$$
A 1, A 2, A 3, A 4, A 5
$$

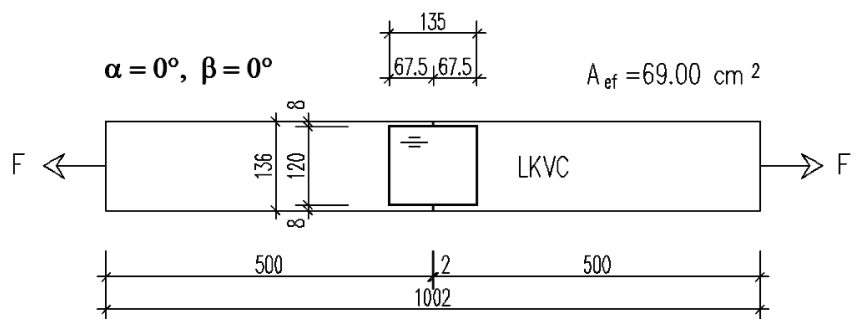

$\mathrm{C1}, \mathrm{C2}, \mathrm{C} 3, \mathrm{C4}, \mathrm{C5}$

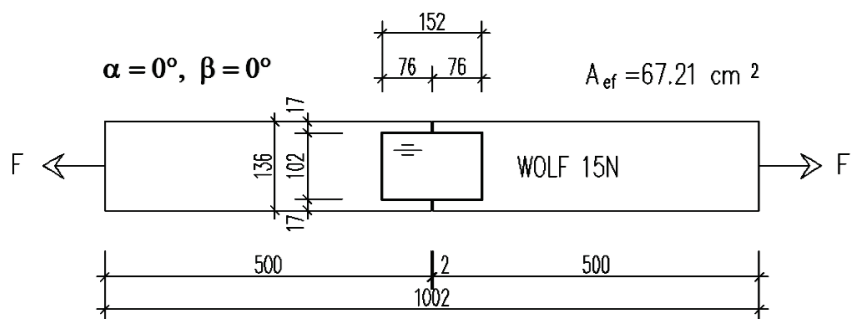

Figure 2 Types of samples of series A and series $\mathrm{C}$ 


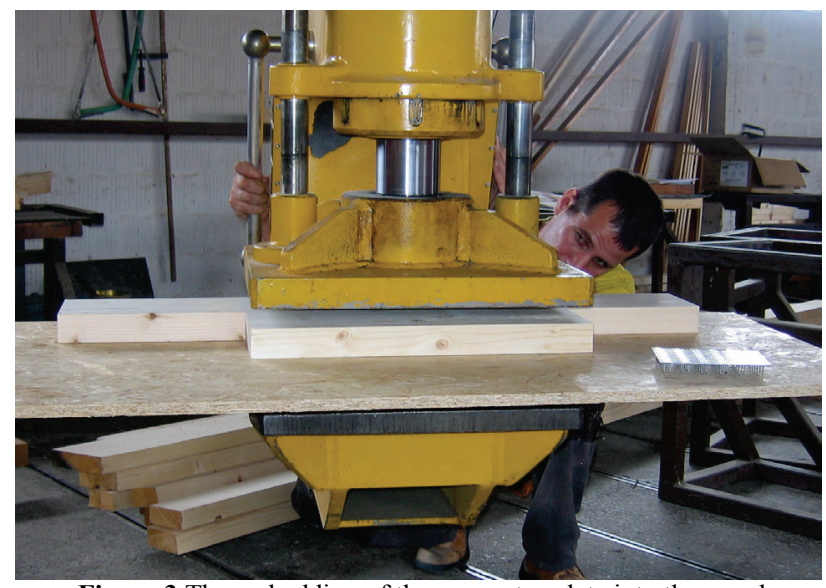

Figure 3 The embedding of the connector plate into the wood

\section{Experimental testing procedure}

Experimental determination of load bearing capacity of connection of timber elements requires implementation of specific tests in laboratories, which are equipped for this purpose, in order to obtain specific information on the strength of these connections. Preparation of test samples included conditioning of the wooden elements, prior to the construction of the joints, and then the conditioning of the finished samples, after the connection was formed. According to ISO 554 standard, atmosphere for the preparation of samples is 20/65, which means the air temperature of $20^{\circ}$ and humidity of $65 \%$. By respecting these rules, load bearing capacity of the tested connections can be compared, including the comparison of the test results from different laboratories.

Testing of the load bearing capacity of realized connections was performed in the Institute of Materials and Structures, at the Faculty of Civil Engineering in Belgrade, on the hydraulic tensile testing machine, made by Amsler. During the application of particular force, deformations were registered with mechanical deformation indicators, with $0,01 \mathrm{~mm}$ accuracy, which were positioned in joint area in order to obtain relevant values of deformations in the connection (Fig. 4). Two of these mechanical deformation gauges were positioned on each sample, in order to record the deformation of connection on both sides of the sample.

Testing procedure was conducted according to EN 26891 [9]. Load was applied in value of $40 \%$ of the estimated maximum load $\left(0,4 \cdot F_{\text {est }}\right)$ and retained for 30 seconds. After that, the deformation was read, as well as load that caused that deformation. Then the load was reduced to a value of $0,1 \cdot F_{\text {est }}$ and retained for 30 seconds, whereupon reading was carried out. The load was then raised until limit load or sliding was attained. Loads up to the value of $0,7 \cdot F_{\text {est }}$ were approximately $0,2 \cdot F_{\text {est }}$ per minute, while for the values above $0,7 \cdot F_{\text {est }}$ limit load or sliding was attained in about 3 to 5 minutes. Total test time of one sample was between 10 and 15 minutes. Application of tensile force was carried out through certain mechanical additions (Fig. 4), with an increment of $4,0 \mathrm{kN}$, and it was in line with loading procedure, in function of estimated maximal load. Destruction of connections occurred only due to overdrawn allowable displacements of the connection. Testing of each sample was discontinued after the destruction of connection, at the time when connector's teeth pulling out of wood started, with displacements of connections in the range between $3,0 \mathrm{~mm}$ and $4,0 \mathrm{~mm}$.
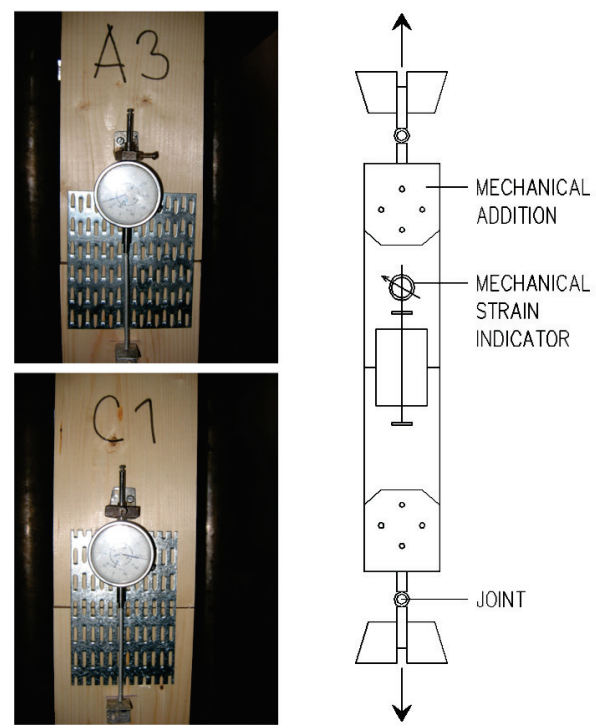

Figure 4 Samples of series A (LKVC) and series C (WOLF)
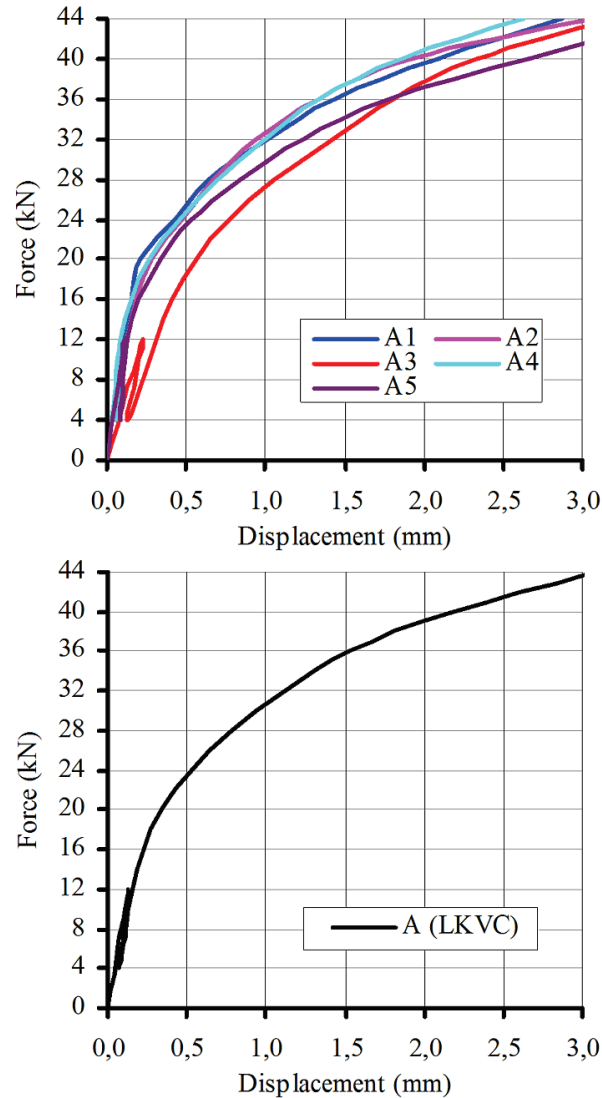

Figure 5 Force-displacement diagram (individual and mean value)

\section{Results of the experimental testing}

Results of the experimental testing, for both connector types, are shown on the force-displacement diagrams. Diagrams show the individual values of connection displacement and the mean average value (Fig. 5 and Fig. 6). The individual values of displacements represent the mean values of displacements on both sides of the sample. It should be emphasized that the differences between displacements of connections at 
different sides of the sample were recorded, with the size of a few hundredths of a millimetre. This data are not shown in the paper since they are not of crucial importance for the comparative analysis of load bearing capacity of two types of connectors, whose load bearing capacity is presented in the paper.
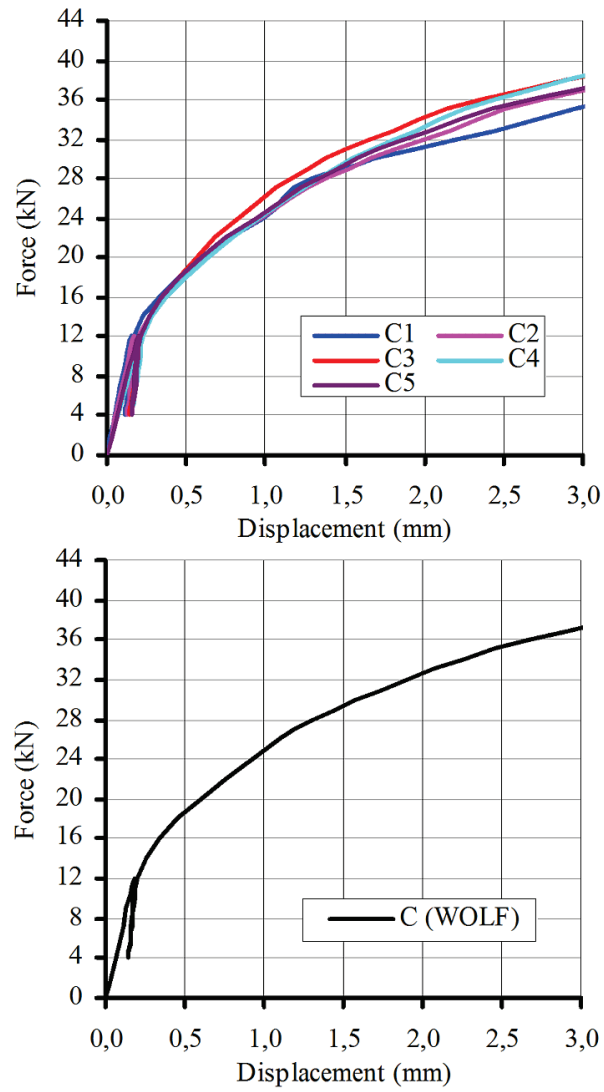

Figure 6 Force-displacement diagram (individual and mean value)

Table 1 Test results
\begin{tabular}{|c|c|c|c|c|c|}
\hline & \multicolumn{3}{|c}{ Load } & \multicolumn{3}{c|}{ Displacement } \\
\hline Sample & $F_{\text {est }} / \mathrm{kN}$ & $F_{\max } / \mathrm{kN}$ & $v_{01} / \mathrm{mm}$ & $v_{04} / \mathrm{mm}$ & $v_{\max } / \mathrm{mm}$ \\
\hline $\mathrm{A} 1$ & 32 & 36,42 & 0,040 & 0,105 & 2,870 \\
\hline $\mathrm{A} 2$ & 32 & 37,15 & 0,060 & 0,125 & 3,070 \\
\hline $\mathrm{A} 3$ & 32 & 32,87 & 0,130 & 0,310 & 3,210 \\
\hline $\mathrm{A} 4$ & 32 & 37,23 & 0,050 & 0,090 & 2,625 \\
\hline $\mathrm{A} 5$ & 32 & 33,96 & 0,090 & 0,135 & 3,570 \\
\hline $\mathrm{C} 1$ & 32 & 28,92 & 0,120 & 0,175 & 4,135 \\
\hline $\mathrm{C} 2$ & 32 & 28,78 & 0,130 & 0,195 & 3,905 \\
\hline C3 & 32 & 30,72 & 0,145 & 0,220 & 3,505 \\
\hline C4 & 32 & 29,42 & 0,160 & 0,225 & 3,415 \\
\hline C5 & 32 & 29,26 & 0,150 & 0,210 & 3,890 \\
\hline
\end{tabular}

Characteristic parameters in accordance with EN 26891 are shown in Tab. $1\left(F_{\text {est }}\right.$ - estimated maximum load, $F_{\max }$ - maximum load for the adopted allowable displacements of connection, $v_{01}$ - displacement for the value of $10 \%$ of estimated maximal load, $v_{04}$ displacement for the value of $40 \%$ of estimated maximum load i $v_{\max }$ - maximum displacement of connection during testing). Load $F_{\text {est }}$ was estimated for the allowable displacements of $1,5 \mathrm{~mm}$ [10]. In the discussion of the test results, ratio of the value of applied load and the measured displacement of connection was analysed, respectively, the limit bearing capacity of connections in function of defined allowable displacement are given.

\section{Discussion of the test results}

Diagrams of fasteners displaceability, mainly obtained experimentally, are as a rule non-linear and different for each fastener type, for each connection type, and depend on many factors. This shows that the unification of the standard diagrams of fasteners displaceability is impossible. Therefore, the approach to this very complex problem is different. The basic way to solve the problem is to approximate displaceability diagram, as a rule, with linear relationship between force and displacement for the lower level of load and with nonlinear relationship for the higher level of load. Many authors have defined load bearing capacity of fasteners only on the basis of fracture force, not taking into account the displacements, which in certain cases defines the limit force value at large displacements. As a criterion, lately, limitation of the displacements in the determination of the open hole compressive strength is introduced. According to the data from UK this limit is $2,1 \mathrm{~mm}$ and according to German research it is $5 \mathrm{~mm}$. So, the conclusion is that the load bearing capacity of fastener can be defined in function of fracture force, namely, in the state of physical destruction of connection, or in the function of exceeding certain value of displacement [11].

Based on the given diagrams, the differences in displacements of connections realized by metal connectors of both manufacturers, can be noted, for the same values of the applied load. For all samples, for LKVC and for WOLF connectors, minor differences in displacements to the extent of $0,4 \cdot F_{\text {est }}$ can be noted, whereupon the increase of deformation is higher for connector WOLF, relative to connector LKVC, for the same value of applied load. Effective surface for connector LKVC is only 2,66 \% higher than for connector WOLF, so, for the same value of displacement, a higher load bearing capacity of the connector LKVC per unit area can be stated, for the corresponding limit force and effective surface, compared to connector WOLF. If we define a limit bearing capacity as a magnitude of displacement and limiting factor, and if we consider values of displacements in steps of $0,5 \mathrm{~mm}$, the differences in load bearing capacity of these two types of connectors can be stated (Fig. 7). With a higher allowable displacement of the connection, ratio of limit bearing capacity becomes smaller and ranges from $24,09 \%$ to $14,86 \%$, just before testing was stopped, that is, just before the connector's teeth pulling out of wood was noted.

Having in mind that testing was conducted in accordance with standard ISO 554, and the fact that the same class of wood, with the same density, was used for all samples, value of $c=0$ is taken for dimensionless coefficient c (1), from the provisions of EN 1075 and EN 28970. In this way the effect of ratio of characteristic and real wood density on the load bearing capacity of connection is excluded. Accordingly, limit plate anchorage capacities are determined, for the displacements of connection in steps of $0,5 \mathrm{~mm}$ (Fig. 7 and Tab. 2), as well as the ratio between limit plate anchorage capacities of connectors LKVC and WOLF (Fig. 8) 


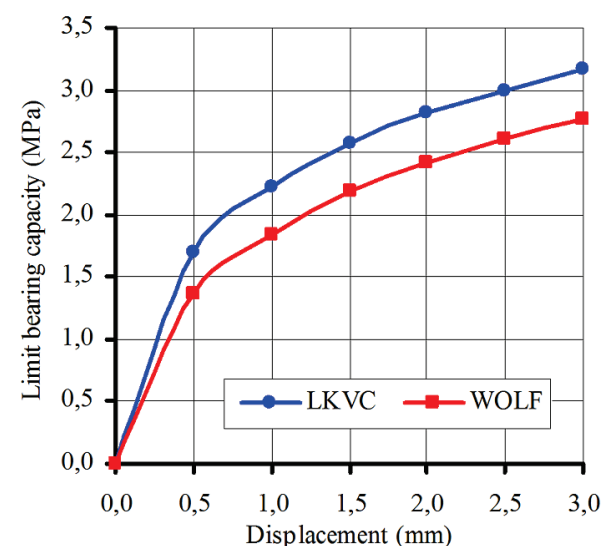

Figure 7 Limit bearing capacity of connection

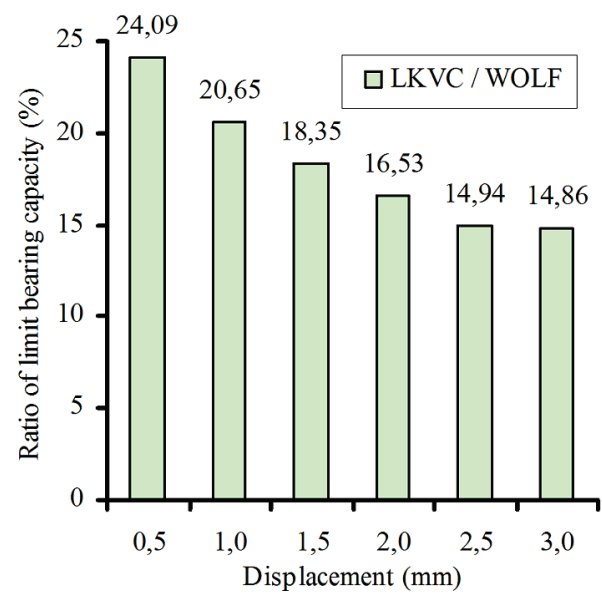

Figure 8 Ratio of limit bearing capacity

Table 2 Limit bearing capacity of connections

\begin{tabular}{|c|c|c|c|c|c|c|c|}
\hline \multirow{2}{*}{$f_{\mathrm{a}, \alpha, \beta} / \mathrm{MPa}$} & \multicolumn{7}{|c|}{ Displacement $(\mathrm{mm})$} \\
\cline { 2 - 8 } & 0,5 & 1,0 & 1,5 & 2,0 & 2,5 & 3,0 \\
\hline Lkvc & $f_{\mathrm{a}, 0,0}$ & 1,70 & 2,22 & 2,58 & 2,82 & 3,00 & 3,17 \\
\hline Wolf & $f_{\mathrm{a}, 0,0}$ & 1,37 & 1,84 & 2,18 & 2,42 & 2,61 & 2,76 \\
\hline \multicolumn{2}{|c|}{ Lkvc/Wolf / \% } & 24,0 & 20,6 & 18,3 & 16,5 & 14,9 & 14,8 \\
\hline
\end{tabular}

If number of teeth per unit area is taken into consideration, load bearing capacity of one tooth can be determined (Tab. 3). Load bearing capacity of one tooth of WOLF connector, for the limit displacement of 1,5 $\mathrm{mm}$, is approximately $8 \%$ higher than the load bearing capacity of LKVC connector tooth, and it increases with the increase of limit displacement. This data is not relevant for load bearing capacity of connections, in terms of dimensioning of the connection, because bearing capacity of connector is expressed per unit of surface area and not by bearing capacity of one tooth. This data can be useful during the designing of connector's geometry and geometry of tooth, in order to increase the connector load bearing capacity, in function of degree of the teeth entrapment. In Figs. 9 and 10 samples in the testing phase are shown, as well as the teeth position relative to the timber, in a moment when testing was stopped.

Table 3 Limit bearing capacity of one tooth

\begin{tabular}{|c|c|c|c|c|c|c|c|}
\hline \multirow{2}{*}{$\begin{array}{c}\text { Bearing capacity } \\
\text { of tooth }\end{array}$} & \multicolumn{7}{|c|}{ Displacement (mm) } \\
\cline { 2 - 8 } & 0,5 & 1,0 & 1,5 & 2,0 & 2,5 & 3,0 \\
\hline Lkvc & $/ \mathrm{N}$ & 287 & 375 & 435 & 476 & 506 & 535 \\
\hline Wolf & $/ \mathrm{N}$ & 294 & 395 & 468 & 518 & 561 & 593 \\
\hline \multicolumn{2}{|c|}{ Wolf/Lkvc / \% } & 2,62 & 5,54 & 7,60 & 9,28 & 10,8 & 10,9 \\
\hline
\end{tabular}
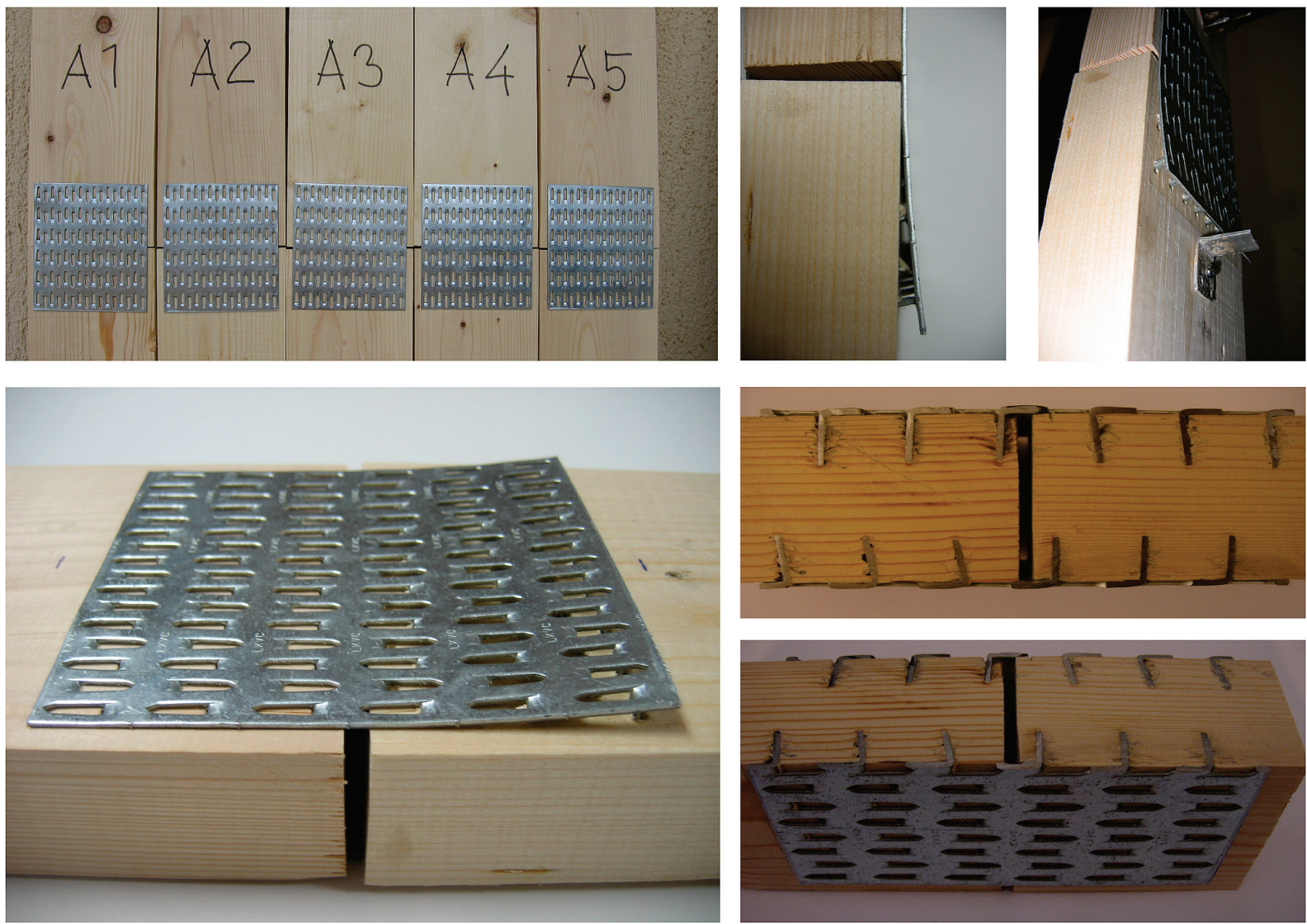

Figure 9 Samples of series A (LKVC) 

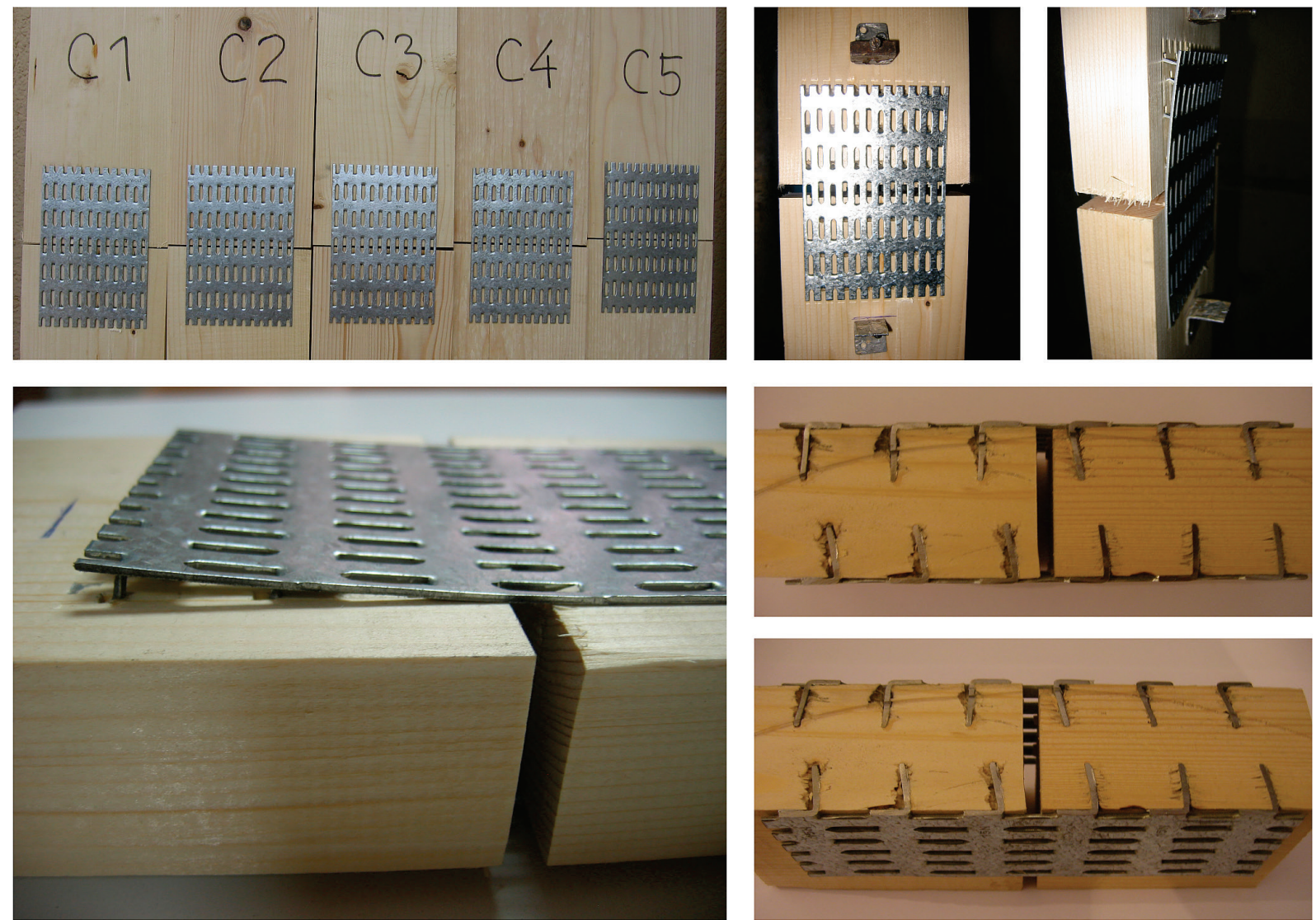

Figure 10 Samples of series C (WOLF)

\section{Conclusion}

Metal connector plates, as modern mechanical fasteners which are used in contemporary timber structures, require special treatment in terms of capacity of realized connections, which should be based on the concept of ultimate limit state and serviceability limit state. For this purpose, experimental testing is performed in accordance with Eurocode 5, for connectors WOLF $15 \mathrm{~N}$ and LKVC, in order to examine the behaviour of these fasteners in timber truss member connections. In addition, the obtained results gave a picture about the relationship between the load bearing capacity of these two types of connectors, in terms of their geometry, for different levels of load applied to timber member connection.

Limit plate anchorage capacity is not determined for adopted allowable displacement, but the behaviour of connection in non-linear part of the diagram was analysed, with sliding of $0,5 \mathrm{~mm}$ to $3,0 \mathrm{~mm}$, in steps of $0,5 \mathrm{~mm}$, namely, rate of increase of limit bearing capacity, with increase in allowable displacement, was determined, with simultaneous inspection of connection compactness. For both connector types there are small differences in load bearing capacity of connection in the elastic region, for the values of displacement up to the 0,2 $\mathrm{mm}$, whereas LKVC connector proved to be of higher quality in the plastic deformation zone. Connector LKVC has a higher load bearing capacity in comparison with WOLF connector for all measured deformation of $0,5 \mathrm{~mm}$ to $3,0 \mathrm{~mm}$. For the displacement of $0,5 \mathrm{~mm}$ load bearing capacity ratio is approximately $24 \%$ and it decreases with increase in deformations, and for the displacement of 3,0 $\mathrm{mm}$ that ratio is approximately $15 \%$.

Experimentally established higher load bearing capacity of one tooth of connector WOLF, for $3 \%$ to 11 $\%$ in comparison to connector LKVC tooth, for different limit displacements, can be justified by greater length of connector WOLF teeth, for $2,0 \mathrm{~mm}$ in comparison to connector LKVC tooth, but also by higher contact surface between the teeth and the wood, for about $30 \%$ in favour of connector WOLF. These data partially justify the determined higher load bearing capacity of one tooth of connector WOLF, in comparison to connector LKVC, but they are not the only parameters that determine the plate anchorage capacity. Number of teeth per unit area of connector proved to be an important factor on which plate anchorage capacity largely depends. The corresponding surface of one tooth of connector WOLF is $27 \%$ higher in relation to that of the connector $\operatorname{LKVC}\left(2,15 \mathrm{~cm}^{2} / 1,69\right.$ $\left.\mathrm{cm}^{2}=1,27\right)$, which came to the fore during the determination of ratio of limit bearing capacity per unit area, in favour of LKVC connector, regardless of higher load bearing capacity of one tooth of connector WOLF.

Teeth root geometry, and degree of their entrapment, are of great importance to the metal connector plate anchorage capacity. It should be noted that the number and geometry of teeth are important not only to the plate anchorage capacity, but also to the stresses in the critical connector cross-section, for different stress states, whose values are closely related to the position and size of the holes in the plate, which remain after perforation of the sheet and after pulling the teeth out of the sheet plane. For the final comparative assessment of the quality of these two types of connectors, it is necessary to have data about 
load bearing capacity of connections for some other combination of angles $\alpha$ and $\beta$, for defined displacements of the connection, and to analyse the load bearing capacity of the critical connector cross-section in tension, compression and shear, because the quality of metal connector is reflected in the equal plate anchorage capacity and plate capacity, and not only in the one or the other capacity.

Experimentally established values of plate anchorage capacity, for angle $\alpha=0^{\circ}$ and $\beta=0^{\circ}$, are a valuable step forward in order to examine the quality and to improve the connections realized by metal connector plates, in modern timber structures. Allowable displacement of the connection of $1,5 \mathrm{~mm}$, prescribed by local regulations, which has been successfully applied to all mechanical fasteners, must be corrected on a higher value than the prescribed, and must be $3,0 \mathrm{~mm}$ for the connections realized by metal connector plates. This view is confirmed by results of the conducted experimental testing of load bearing capacity of realized connections, which, including partial safety coefficients prescribed by the Eurocode 5, should provide safe and cost-effective connection of timber elements, and they also include the continuation of research in this area.

\section{Acknowledgements}

The authors would like to thank Prof. Dr. Vojislav Kujundžić for his support and expert assistance, LKV Center from Belgrade for help related to the formation of samples for experimental testing and the Institute of Materials and Structures at Faculty of Civil Engineering in Belgrade for assistance related to the experimental testing.

\section{References}

[1] Tekić, Ž. Savremeni koncepti primene metalnih konektera u sistemima drvenih struktura, Doktorska disertacija, Arhitektonski fakultet Univerziteta u Beogradu, Beograd, 2005.

[2] Karakteristike konektera LKVC, $\mathrm{http}: / / w w w . l k v c e n t a r . c o m / l k v-l a k i-k r o v n i-v e z a c i / k o n e k t e r$

[3] Karakteristike konektera WOLF, http://www.wolfsystem.at/Nagelplatten/Nagelplatten-Typen

[4] EN 10147:2000. Specification for continuously hot-dip zinc coated structural steel sheet and strip - Technical delivery conditions.

[5] Eurocode 5: Design of timber structures. EN 1995-1-1, Part 1-1: General - Common rules and rules for buildings, 2004, Brussels: European committee for standardization.

[6] EN 1075:1999. Timber structures - Test methods. Testing of joints made with punched metal plate fasteners.

[7] EN 28970:1991. Timber structures. Testing of joints made with mechanical fasteners; requirements for wood density (ISO 8970:1989).

[8] EN 14545. Timber structures - Connectors - Requirements.

[9] EN 26891:1991. Timber structures. Joints made with mechanical fasteners. General principles for the determination of strength and deformation characteristics.

[10] SRPS U.C9.200. Projektovanje i izvodenje drvenih konstrukcija - Konstrukcije od monolitnog drveta i ploča.

[11] Stojić, D.; Cvetković, R. Nosivost i pomerljivost spojnih sredstava u savremenim drvenim konstrukcijama, Zbornik radova Građevinsko-arhitektonskog fakulteta, 20, Niš, 2004, pp. 77-84.

\section{Authors' addresses}

Žikica Tekić, Ph.D. Assistant Professor

University of Belgrade, Faculty of Architecture, Bulevar kralja Aleksandra 73, 11000 Beograd, Serbia E-mail: ztekic@arh.bg.ac.rs

Aleksandra Nenadović, M.Sc. Teaching Assistant University of Belgrade, Faculty of Architecture, Bulevar kralja Aleksandra 73, 11000 Beograd, Serbia E-mail: aleksandra@arh.bg.ac.rs

Saša Đorđević, M.Sc. Teaching Assistant University of Belgrade, Faculty of Architecture, Bulevar kralja Aleksandra 73, 11000 Beograd, Serbia E-mail: sasadj@arh.bg.ac.rs

Jefto Terzović, M.Sc. Teaching Assistant University of Belgrade, Faculty of Architecture, Bulevar kralja Aleksandra 73, 11000 Beograd, Serbia E-mail: terzovic@gmail.com 


\section{Open to all organizers of scholarly and scientific conferences!}

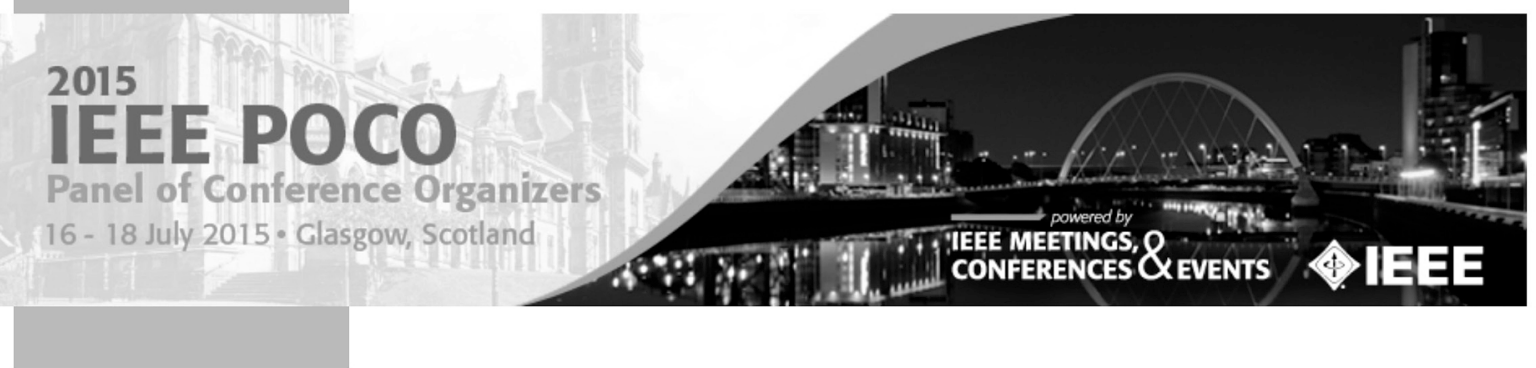

Don't Miss Your Opportunity to:

- Understand IEEE best practices for conference organizing

- Chart the course of best practices in scholarly publishing

- Explore new conference formats and ideas

- Check out the latest in event technology

- Discover how to create a culture of innovation for your events

\section{Hilton}

\section{Glasgow}

1 William St, Glasgow G3 8HT, United Kingdom

Room Rate

Single $£ 130$ Double $£ 140$

Registration Rates

Hosted Attendee - Complimentary

Full - US\$325

Companion - US $\$ 150$

Day 1

IEEE Conference Education

Day 2

Excellence in Scholarly

Conferences

Day 3

Innovation Infusion

\section{Convening the Conference Community}

The IEEE Panel of Conference Organizers (POCO) is the annual event for leading scholarly conference organizers around the world.

\section{IEEE organizes this event to}

share resources and ideas with all scientific associations and nonprofit conference organizers.

POCO convenes thought leaders and decision makers to address conference leadership practices, discuss challenges in the conference landscape, envision the future and launch new conference initiatives.

Attendees will have the opportunity to network and share ideas with the full scientific association community.

Join organizers from more than 28 countries to discover, discuss, and design new innovations for your conference. The thought provoking discussion includes:

- What are IEEE best practices for conferences?

- How will new tech trends and tools impact my events?

- How can we deliver quality content in a world of computer-generated papers?

- Is the peer review model still viable?

- How can I understand and use social media?

- How do cultural differences impact scholarly publishing around the world?

- Will open access kill conference publication?

- How can we justify conference attendance to employers?

- How can we create a culture of innovation?

- What is the future of scholarly conferences?

IEEE Volunteers involved in conferences can apply to attend as a hosted attendee and receive complimentary registration. Contact ieee-mce@ieee.org for an invitation, or visit http://ieee.org/go/poco

Many IEEE Organizational Units will cover the cost of travel and lodging. Check with yours as soon as possible for this can't-miss event
IEEF

445 Hoes Lane Piscataway, NJ 08854 USA

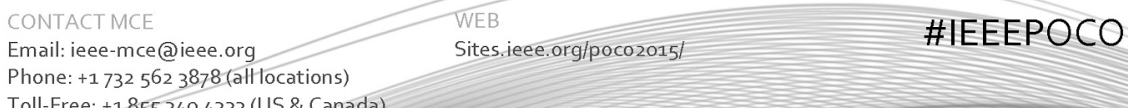

Email: ieee-mce@ieee.org
Phone: +17325623878 (alllocations)

Toll-Free: +18553404333 (US \& Canada) 